\title{
Seaglider observations of variability in daytime fluorescence quenching of chlorophyll-a in Northeastern Pacific coastal waters
}

Fluorescene quenching from

Seaglider

B. S. Sackmann et al.

\section{B. S. Sackmann ${ }^{1}$, M. J. Perry ${ }^{2}$, and C. C. Eriksen ${ }^{3}$}

${ }^{1}$ Monterey Bay Aquarium Research Institute, Moss Landing, CA 93907, USA

${ }^{2}$ School of Marine Sciences, Ira C. Darling Marine Center, University of Maine, Walpole, ME 04573, USA

${ }^{3}$ School of Oceanography, University of Washington, Seattle, WA 98195, USA

Title Page

Abstract Introduction

Conclusions

Tables References Figures

14

4

Back Close

Received: 12 June 2008 - Accepted: 12 June 2008 - Published: 9 July 2008

Full Screen / Esc

Correspondence to: B. S. Sackmann (sackmann@ @ mbari.org)

Published by Copernicus Publications on behalf of the European Geosciences Union.

Printer-friendly Version

Interactive Discussion 


\section{Abstract}

The use of new autonomous and Lagrangian platforms (e.g. gliders, drifters, etc.) has revolutionized sampling of the ocean. The incorporation of in vivo chlorophyll-a fluorometers into these platforms for characterizing chlorophyll-a concentrations and

5 phytoplankton biomass has reinforced the need for a thorough understanding of the variability and biases associated with basic fluorescence measurements. Seaglider, a long-range autonomous glider, has been deployed routinely in Northeast Pacific waters off the Washington coast, USA. Measurements of chlorophyll-a fluorescence (proxy for chlorophyll-a concentration) and optical backscattering (proxy for particle concentration) were collected on the continental shelf and along a V-shaped transect that extended $200 \mathrm{~km}$ from the continental shelf into deep oceanic waters. Daytime fluorescence quenching (i.e. the reduction in the fluorescence quantum yield often observed during daylight hours) could be detected throughout the dataset, with near-surface daytime fluorescence quenched by as much as $80 \%$ during summer. Quenching was 15 observed throughout the region, at all times of year, and to depths greater than $50 \mathrm{~m}$. The degree of quenching was positively correlated with incoming solar radiation and the observed pattern was remarkably similar to what has been observed in other areas, suggesting some degree of universality for the underlying relationship.

\section{Introduction}

20 The ease with which in vivo fluorescence of chlorophyll-a can be measured in the ocean has led, in part, to its routine use as a proxy for in situ pigment concentrations (e.g. chlorophyll-a) and phytoplankton distributions since the mid 1960's (Lorenzen 1966). However, early observations also showed that when in vivo fluorescence measurements were normalized to extracted chlorophyll-a concentrations, the resulting fluorescence-to-chlorophyll a ratio could vary by as much as ten-fold over relatively short spatial and temporal scales (Loftus and Seliger, 1975; Alpine et al., 1979; Cullen,

BGD

$5,2839-2865,2008$

\section{Fluorescene quenching from Seaglider}

B. S. Sackmann et al.

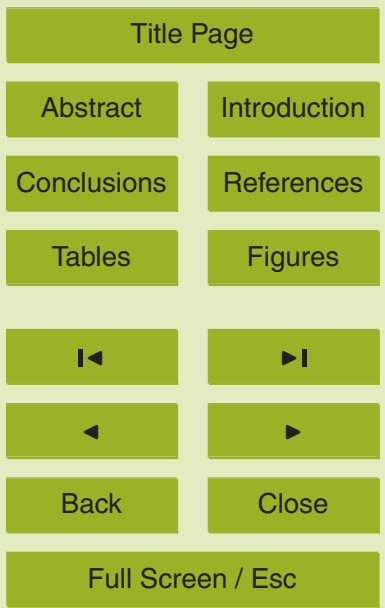

Printer-friendly Version

Interactive Discussion 
1982). This variability has a wide range of underlying causes and has been related to changes in species and pigment composition (Strickland, 1968; Slovacek and Hannan, 1977; Neori et al., 1984), phytoplankton size and intra-cellular organization of the chloroplasts, light history, nutrient stress (Kiefer, 1973a, b; Loftus and Seliger, 1975;

5 Slovacek and Hannan, 1977; Alpine and Cloern, 1985), as well as a host of internal photosynthetic and physiological processes (Kiefer and Reynolds, 1992; Falkowski and Kolber, 1995). In natural populations it is often difficult to separate the effects that these factors have on overall fluorescence efficiency, since many different processes can act simultaneously.

10 In both laboratory studies and in the field, researchers have observed a daily rhythm of in vivo fluorescence that is not correlated with diel changes in the concentration of chlorophyll-a. During periods of high irradiance fluorescence tends to be lower than it is at night (Kiefer, 1973a; Loftus and Seliger, 1975; Falkowski and Kolber, 1995; Dandonneau and Neveux, 1997; Behrenfeld and Kolber, 1999; Kinkade et al., 1999). 15 The decrease in the fluorescence quantum yield (i.e. the ratio of photons emitted as fluorescence to those absorbed by photosynthetic pigments) is often ascribed to a set of processes generally termed non-photochemical fluorescence quenching (NPQ; Falkowski, 1992; Falkowski and Kolber, 1995; Krause and Jahns, 2004).

The two major components of NPQ are "photoinhibitory quenching" and "energydependent quenching". Photoinhibitory quenching is thought to arise from damage to the PSII reaction center protein, D1, which leads to enhanced thermal dissipation of absorbed excitation energy within the reaction center (Takahashi et al., 1971; Ohad et al., 1990; Falkowski et al., 1994; Krause and Jahns, 2004). The effects of photoinhibition increase non-linearly as a function of photon-dose; recovery is rela25 tive slow (O (hours)) as it requires the synthesis of new D1 protein by the organism (Kyle et al. 1984) and because additional D1 protein damage can occur under both intermediate and high irradiance conditions (Falkowski, 1992). Unlike photoinhibitory quenching, which reflects actual damage to the photosynthetic machinery within a phytoplankton cell, energy-dependent quenching is associated with short-term variations

BGD

$5,2839-2865,2008$

\section{Fluorescene quenching from Seaglider}

B. S. Sackmann et al.

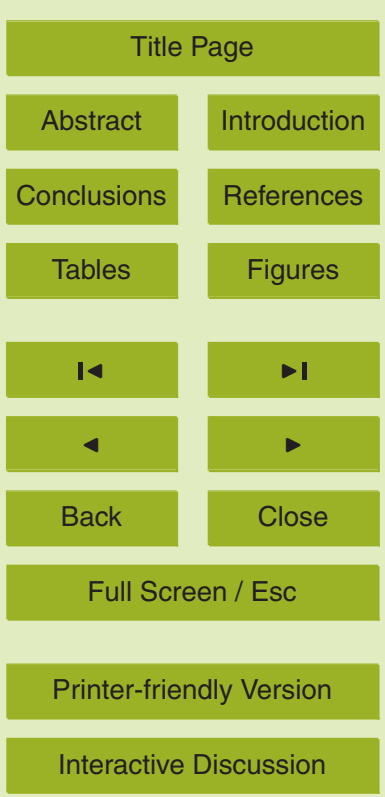


(O (minutes)) in the functional absorption cross-section of PSII and enhanced thermal dissipation in the antennae (Falkowski and Kolber, 1995; Krause and Jahns, 2004). In many types of algae this process is correlated with light-mediated and reversible changes in various oxygenated carotenoids known as xanthophylls (Demmig-Adams 5 and Adams, 1992). Regardless of the underlying cause (i.e. photoinhibitory and/or energy-dependent quenching), the net result is often systematic decreases in fluorescence per unit chlorophyll-a observed during periods of increased irradiance. For this reason we refer to the observed pattern more generally, as daytime fluorescence quenching.

10 The lack of a universal relationship between in vivo fluorescence and chlorophyll-a has been a source of ongoing frustration for researchers, as it decreases accuracy in determinations of chlorophyll concentration from in vivo fluorescence. However, this variability also contains important clues about the physiology of phytoplankton assemblages. The challenge, particularly for the new approaches to ocean observing that use autonomous and Lagrangian platforms (e.g. gliders, drifters), is to learn how to use patterns of change in in vivo fluorescence to infer information about phytoplankton abundance, physiology and primary productivity. In this paper we report a unique 17-month dataset collected by Seaglider, a long-range autonomous glider deployed routinely in Northeast Pacific waters off the Washington coast, USA, that has allowed us to characterize ubiquitous patterns of variability in daytime fluorescence quenching across a range of temporal scales, from days to years, and a function of light.

\section{Data and methods}

\subsection{Description of Seaglider deployments}

Seaglider is an autonomous underwater glider that samples the ocean in a sawtooth pattern (Eriksen et al., 2001). To date, two types of deployments have been conducted off the Washington coast to a maximal depth of $1000 \mathrm{~m}$ (Fig. 1). The first was

BGD

5, 2839-2865, 2008

\section{Fluorescene quenching from Seaglider}

B. S. Sackmann et al.

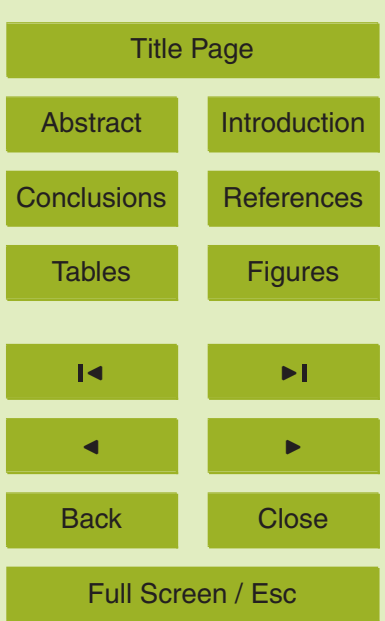

Printer-friendly Version

Interactive Discussion 
a "higher temporal resolution-shorter duration" mission that was carried out in April 2002 (Fig. 1b). Seaglider was launched at the mouth of the Strait of Juan de Fuca and was programmed to make its way towards the southwest, across the Washington continental shelf and into waters overlying the slope. Once Seaglider moved beyond 5 the strong tidal currents near the entrance to the Strait of Juan de Fuca, it took $6 \mathrm{~d}$ to cross the continental shelf (approx. $75 \mathrm{~km}$ ) and made approximately 150 dives to an average depth of $125 \mathrm{~m}$ (approx. 25 dives $\mathrm{d}^{-1}$ with $0.5 \mathrm{~km}$ spacing between dives; data in Figs. 2-4). Since August 2003 Seaglider has been conducting "lower temporal resolution-longer duration" missions along a V-shaped transect (approx. $450 \mathrm{~km}$ ) 10 that extends from the shelf-slope break into oceanic waters off the Washington coast (Fig. 1c, data in Figs. 5-8). Completion of one V-shaped transect takes Seaglider an average of $30 \mathrm{~d}$ during which it makes approximately 90 dives to a depth of $1000 \mathrm{~m}$ (approx. 3 dives $\mathrm{d}^{-1}$ with $5 \mathrm{~km}$ spacing between dives). Typically, this type of Seaglider deployment lasts 5-6 months.

15 During each dive Seaglider measures a suite of parameters that includes conductivity (Sea-Bird Electronics SBE 4), temperature (Sea-Bird Electronics SBE 3), pressure (Paine Corporation 211-75-710-05 1500PSIA), dissolved oxygen (DO; Sea-Bird Electronics 43F Clark-type oxygen electrode), chlorophyll-a fluorescence (proxy for phytoplankton concentration), two wavelengths of optical backscattering by particles $20 \quad\left(\mathrm{~b}_{b p}(470)\right.$ and $\mathrm{b}_{b p}(700)$; proxies for particle concentration), and GPS position. Measurements of $b_{b p}(\lambda)$ and fluorescence are obtained from a single miniaturized instrument, the ECO-BB2F, which was developed by WET Labs specifically for Seaglider; chlorophyll-a fluorescence is excited at $470 \mathrm{~nm}$ and emission measured at $682 \mathrm{~nm}$, sharing the same broad-band detector as $b_{b p}(700)$. Because Seaglider usually ascends more slowly than it descends, "up-casts" are more highly resolved near the surface. For this reason we chose to limit our statistical analyses to data from up-cast profiles only.

BGD

$5,2839-2865,2008$

\section{Fluorescene quenching from Seaglider}

B. S. Sackmann et al.

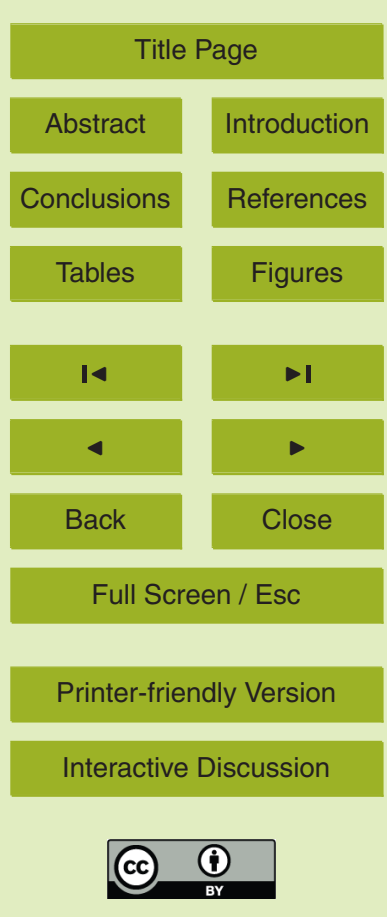


At recovery the optical face of the ECO-BB2F appears clean with little to no bio-fouling, most likely because the gliders are typically deployed seaward of the biologically-rich shelf; they spend little time in the euphotic zone $(<5 \%)$ and most time at low temper-

5 atures and high pressures. An instrument-specific clean water background, equivalent to the lowest value observed at $150 \mathrm{~m}$, was subtracted from the raw instrument counts; the background was typically lower than the manufacturer's clean water signal. From August 2003-December 2005 three different ECO-BB2F sensors were used during the various Seaglider deployments. For this dataset only relative measures of fluorescence and $b_{b p}(700)$ were analyzed to ensure that results from the different sensors would be comparable (e.g. Figs. 5-8).

\subsection{SeaWiFS snstantaneous surface PAR and chlorophyll concentrations}

Estimates of daily photosynthetically active radiation (i.e. 24-h averaged or dailyPAR) were obtained using radiometric measurements from the Sea-viewing Wide 15 Field-of-View Sensor (SeaWiFS). The SeaWiFS project defines daily-PAR at the sea surface as the quantum energy flux from the Sun in the spectral range from 400$700 \mathrm{~nm}$ expressed in mol photons $\mathrm{m}^{-2} \mathrm{~d}^{-1}$. Level 3 binned data files with $9 \mathrm{~km}^{2} \mathrm{spa}$ tial resolution and a 1-d temporal bin width were obtained from NASA's OceanColor WEB (http://oceancolor.gsfc.nasa.gov). Detailed algorithm descriptions and processing methodologies can be found on NASA's OceanColor WEB website.

Each Level 3 binned data file was mapped using an isotropic Transverse Mercator projection with an average pixel size of $1.1 \mathrm{~km}^{2}$. A time series of daily-PAR was created by calculating the median daily-PAR value observed within $50 \mathrm{~km}$ of Seaglider's position. A smooth sinusoidal curve (from sunrise to sunset) was used to estimate time25 resolved, instantaneous PAR (iPAR; expressed in $\mu \mathrm{mol}$ photons $\mathrm{m}^{-2} \mathrm{~s}^{-1}$ ) from the 24-h averaged quantities provided (Kirk, 1994). The integral of iPAR, from sunrise to sunset, is numerically equivalent to the daily-PAR estimates recorded by SeaWiFS. Local times

\section{Fluorescene quenching from Seaglider}

B. S. Sackmann et al.

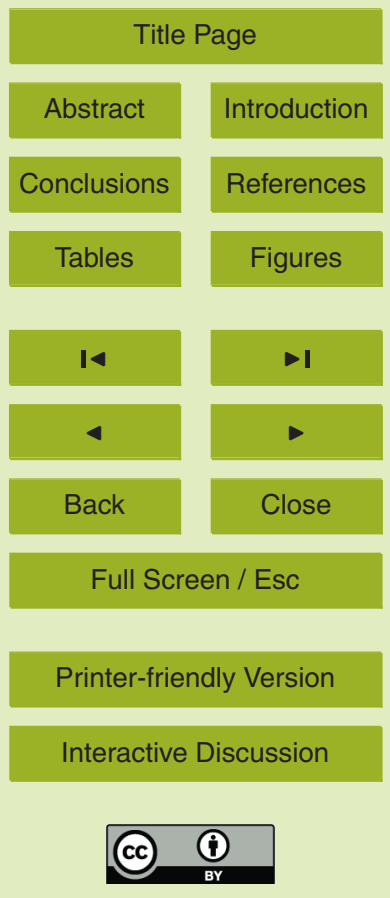


for sunrise and sunset were calculated using functions from the "AIR_SEA" toolbox developed for Matlab (http://woodshole.er.usgs.gov/operations/sea-mat/air_sea-html/ index.html).

To compare spatial patterns of variability between Seaglider fluorescence and 5 SeaWiFS-derived estimates of chlorophyll-a, a matchup procedure was developed to extract ocean color data from a single satellite image along a Seaglider transect. Seaglider's position was obtained via GPS at the end of each dive cycle while the vehicle was at the surface (one GPS fix is obtained immediately after surfacing and another just prior to the next dive). Standard Level 2 ocean color data files from NASA's 10 OceanColor WEB contain georeferencing information for each observation (i.e. pixel) in a scene; satellite data were summarized as a median of all observations within $2.5 \mathrm{~km}$ of a Seaglider GPS fix. With this positional information near-surface optical measurements from Seaglider were matched with co-located satellite measurements for an image from YD 115 (Fig. 4b).

\subsection{Characterizing daytime fluorescence quenching}

The magnitude of fluorescence quenching was assessed using two techniques. In April 2002 during the higher temporal resolution-shorter duration mission, we were able to make measurements in surface waters approximately every $1 \mathrm{~h}$; we used the ratio of fluorescence to optical backscattering ( $\left.F: b_{b p}(700)\right)$ to assess $\sim$ hourly changes in the degree of fluorescence quenching. The mixed layer depth (MLD) was objectively defined as the depth where density increased by $0.125 \mathrm{~kg} \mathrm{~m}^{-3}$ relative to the surface (Monterey and Levitus 1997). At night $\mathrm{F}: \mathrm{b}_{b p}(700)$ was relatively constant throughout the mixed layer. However during the day, fluorescence quenching led to large decreases in $\mathrm{F}: \mathrm{b}_{b p}(700)$ near the surface. The magnitude of quenching was determined 25 by evaluating individual daytime profiles; if values of $F: b_{b p}(700)$ were constant throughout most of the deeper portion of the mixed layer, they were extrapolated to the surface

BGD

$5,2839-2865,2008$

\section{Fluorescene quenching from Seaglider}

B. S. Sackmann et al.

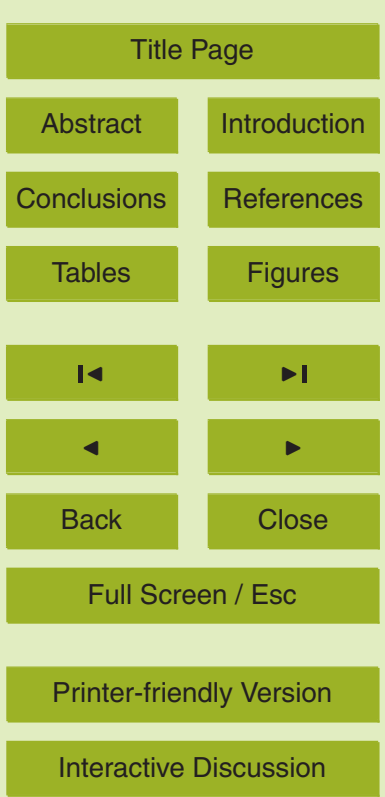


and used to derive estimates of "unquenched" fluorescence:

"unquenched" surface $\mathrm{F}=$ surface $\mathrm{b}_{b p}(700) \times$ deeper $\mathrm{F}: \mathrm{b}_{b p}(700)$

BGD

Each profile was processed independently and assigned a numerical ranking from 1-3 for quality assessment. A value of 1 was used to identify profiles where the method5 ology could be applied successfully and without complications. A value of 2 was used to identify profiles where daytime fluorescence quenching penetrated to a depth below the MLD but a region of uniform $F: b_{b p}(700)$ could still be identified below the estimated MLD; in these cases a value of $F: b_{b p}(700)$ from just below the MLD was extrapolated to the surface. A value of 3 was used to identify profiles where a region of uniform $10 \mathrm{~F}: \mathrm{b}_{b p}(700)$ could not be identified and the method could not be used to estimate "unquenched" fluorescence. Of 151 profiles, 146 were ranked as $1(n=139)$ or $2(n=7)$.

The second more automated technique was primarily used for data collected during the lower-temporal resolution missions carried out between August 2003 and December 2005 when Seaglider made over 2500 dives off the Washington coast. Median 15 fluorescence values from surface $(0-5 \mathrm{~m})$ and subsurface $(5-25,25-50$, and $50-75 \mathrm{~m})$ bins were calculated for each profile, both day and night. $\mathrm{F}_{D}$ was the actual daytime fluorescence measurement (typically affected by daytime fluorescence quenching). For each daytime fluorescence measurement, an unquenched value $\left(F_{N}\right)$ was derived using simple linear interpolation between the two closest (in time) nighttime fluorescence measurements. Nighttime was defined as any time before sunrise or after sunset and the average distance between two nighttime samples was $O(10 \mathrm{~km} / 16 \mathrm{~h})$. The interpolated $F_{N}$ values were considered to represent daytime fluorescence, free from the effects of quenching; the error in this assumption is discussed later (Fig. 5). A fluorescence quenching parameter, DFQ (Daytime Fluorescence Quenching), was calculated:

$\mathrm{DFQ}=\frac{\left(\mathrm{F}_{\mathrm{N}}-\mathrm{F}_{\mathrm{D}}\right)}{\mathrm{F}_{\mathrm{N}}}$

where larger values of DFQ are associated with greater fluorescence quenching. An important property of DFQ is that it is sensor independent, thus allowing for direct 2846

\section{Fluorescene quenching from Seaglider}

B. S. Sackmann et al.

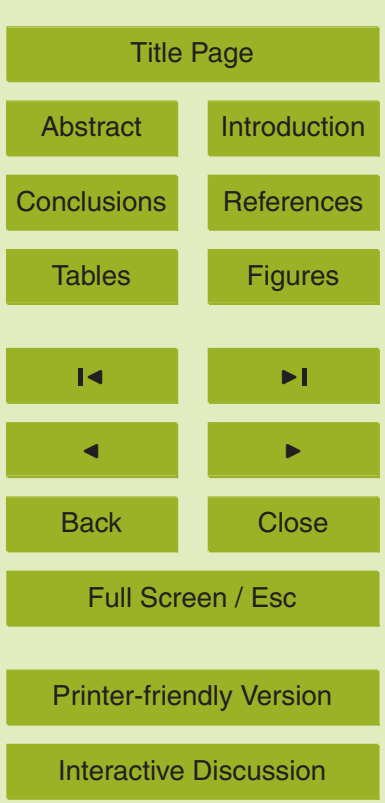


comparisons among all data from different Seaglider deployments. The two techniques were compared for $10 \%$ of the daytime profiles collected from August 2003-December $2005(n=145)$, chosen at random. Both methods provided quantitatively similar results $(r=0.815, p<0.05)$.

\section{$5 \quad 3$ Results and discussion}

\subsection{Optical measurements on the continental shelf in April 2002}

From 22-28 April 2002 (YD 112-118) Seaglider collected high-frequency measurements of fluorescence and $b_{b p}(700)$ as it crossed the continental shelf (Fig. 1b). In addition to large spatial gradients in both fluorescence and optical backscattering observed in the mixed layer (approximately 5X for nighttime unquenched fluorescence and $3 \mathrm{X}$ for optical backscattering; Fig. 2), clear and dramatic depressions in fluorescence could be seen during the day near the surface (Fig. 2a-b). In all cases for the April 2002 dataset on the shelf, quenching of the fluorescence signal was restricted to the upper $10 \mathrm{~m}$ because of the rapid attenuation of light with depth due to the large diffuse attenuation coefficients $\left(\mathrm{K}_{d}\right)$ associated with high phytoplankton biomass (Fig. 2). Data in Fig. 2 are presented as a function of time rather than space to highlight the strong effect of daytime quenching on fluorescence but not on backscattering.

In waters with minimal resuspended sediments, particulate backscattering is correlated with chlorophyll-a, although there is a non-zero backscatter intercept (Perry et al., in press; Stramski and Kiefer, 1991; Stramski et al., 2004, 2008; Vaillancourt et al., 2004). Within the mixed layer on the shelf, gross patterns observed in $b_{b p}(700)$ were indeed similar to those of nighttime fluorescence. The uniformity of $b_{b p}(700)$ within the mixed layer also suggests that the contribution of bubbles to optical backscatter was minimal. Below $25 \mathrm{~m}$ on the shelf the fluorescence signal almost completely disappeared (although after YD 117 when Seaglider moved off the shelf into deep water overlying the continental slope, a subsurface chlorophyll maximum layer was evident
BGD

5, 2839-2865, 2008

\section{Fluorescene quenching from Seaglider}

B. S. Sackmann et al.

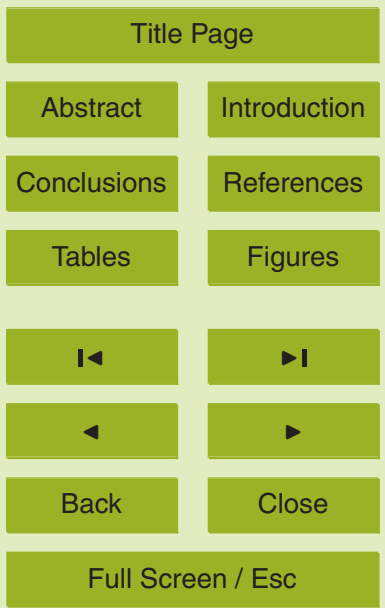

Printer-friendly Version

Interactive Discussion 
below $25 \mathrm{~m}$ ). In contrast to fluorescence in shelf waters, large values of $\mathrm{b}_{b p}(700)$ could be measured at depths below $25 \mathrm{~m}$ (Fig. $2 \mathrm{c}$ ). The very low fluorescence and F: $\mathrm{b}_{b p}(700)$ ratios at depth suggest that the backscattering material was non-biogenic sediment, most likely resuspended by strong tidal currents near the bottom, enhanced up-canyon 5 flows, and/or topographically mediated upwelling associated with the Juan de Fuca canyon system (Freeland and Denman, 1982; Allen, 1996; Foreman and Thomson, 1997; Cummins et al., 2000). The pattern in optical backscattering shows that the resuspended material is primarily restricted to depths close to the bottom; the zone of low particle water evident immediately below the mixed layer (Fig. 2c) indicates that 10 resuspended sediments do not contribute to optical backscattering in the mixed layer.

\subsection{High-resolution temporal measurements of fluorescence quenching on the shelf}

The high spatial and temporal resolution $(\mathrm{O}(0.5 \mathrm{~km} / 1 \mathrm{~h}))$ provided by the April 2002 transect and the simultaneous measurement of both fluorescence and $b_{b p}(700)$ enabled us to characterize the diel pattern of fluorescence quenching. The $F: b_{b p}(700)$ ratio provided a unique optical signature to identify portions of individual fluorescence profiles affected by daytime quenching. Vertical profiles show a uniform $F: b_{b p}(700)$ ratio throughout the mixed layer both before sunrise and after sunset (Fig. $3 a$ and $c$ ). During the daytime, a clear depression in the $\mathrm{F}: \mathrm{b}_{b p}(700)$ ratio $(\mathrm{O}(50 \%))$ is evident near the surface as a consequence of fluorescence quenching (Fig. 3b); this pattern 20 is observed at all daytime locations along Seaglider's transect (Fig. 4a). By extrapolating the deeper-water value of $F: b_{b p}(700)$ to the surface for each profile, we calculate "unquenched" or corrected near-surface fluorescence (Eq. 1; Fig. 4b). We estimate the average error in these quenching-corrected fluorescence values to be $O( \pm 10 \%)$ based on variability in the $\mathrm{F}: \mathrm{b}_{b p}(700)$ ratio observed in the mixed layer in the absence of daytime quenching.

A comparison between the "corrected" fluorescence measurements from Seaglider and satellite-derived estimates of chlorophyll-a from SeaWiFS revealed similar spatial patterns in phytoplankton pigment (Fig. 4b). It should be noted that Seaglider sampled

BGD

5, 2839-2865, 2008

\section{Fluorescene quenching from Seaglider}

B. S. Sackmann et al.

Title Page

Abstract

Introduction

Conclusions

Tables

References

Figures

14

$\rightarrow$

4

Back

Close

Full Screen / Esc

Printer-friendly Version

Interactive Discussion 
over $7 \mathrm{~d}$, while the SeaWiFS data were extracted from a single satellite pass on YD 115. While it may be true that the simple removal of the biased daytime measurements from the dataset would have yielded the same general pattern of phytoplankton biomass across the continental shelf, it would have also hindered our ability to resolve some

5 of the higher-frequency variations $(<12 \mathrm{~h}$ and $<6 \mathrm{~km})$ that may be important in certain applications. By correcting the near-surface fluorescence measurements for the effects of daytime quenching we were able to preserve the high spatial and temporal resolution of the dataset.

Vertical distribution of phytoplankton can be non-uniform, even in a so-called "mixed 10 layer". Using fluorescence alone, it would be difficult to determine if an observed vertical pattern reflects a true decrease in the near-surface phytoplankton vs. the effect of daytime fluorescence quenching; both conclusions would be plausible in the absence of other measurements. However, patterns in the night-time $F: b_{b p}(700)$ ratio in the mixed layer tend to be less variable than patterns in either $F$ or $b_{b p}(700)$ as a 15 function of depth. By using the $\mathrm{F}: \mathrm{b}_{b p}(700)$ ratio, it is possible to make the distinction between changes in the vertical fluorescence profile due to true variations in phytoplankton biomass vs. fluorescence quenching.

The $\mathrm{F}: \mathrm{b}_{b p}(700)$ ratio can also provide insight into changes in the optical properties or physiology of different phytoplankton assemblages, with the caveat that the relative contribution of suspended sediments, other minerals, or bubbles does not change. Over small spatial distances the night-time $F: b_{b p}(700)$ ratios were often remarkably constant $( \pm 10 \%)$; for example, during the nights of YD 112, 113, and 115, the ratio varied little within a single night (Fig. 4a). However, over larger distances, clear changes in the night-time ratios were observed from night-to-night. Particularly striking was the

25 large decrease in $\mathrm{F}: \mathrm{b}_{b p}(700)$ at the transition between the shelf and slope as Seaglider moved off the shelf into deeper waters between YD 116 and 118. Such changes in the optical properties likely reflect changes in phytoplankton community composition, physiology and/or relative concentration of detrital material; validation and further investigation is required.

BGD

5, 2839-2865, 2008

\section{Fluorescene quenching from Seaglider}

B. S. Sackmann et al.

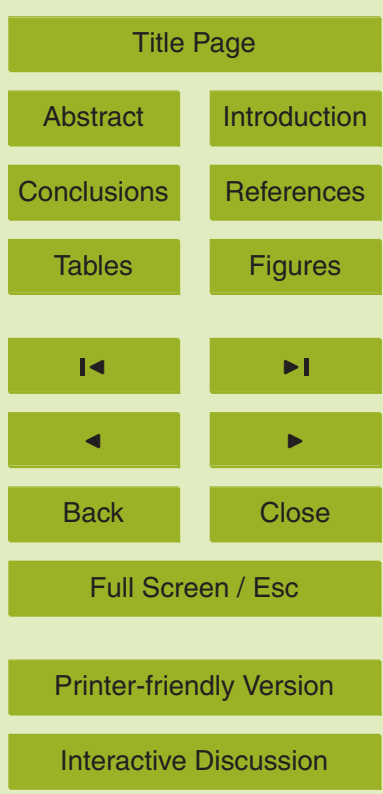


3.3 Seasonal and inter-annual patterns of near-surface $(0-5 \mathrm{~m})$ fluorescence quenching (August 2003-December 2005)

BGD

With the longer time series we hoped to determine whether the diel patterns in fluorescence quenching observed over the continental shelf in April 2002 were ubiqui5 tous throughout all Seaglider missions. Seaglider typically began its "lower temporal resolution-longer duration" missions seaward of the shelf-slope break (>250 m depth; Fig. 1c) and then moved offshore into more oligotrophic waters $\left(<1 \mathrm{mg} \mathrm{chl} \mathrm{a} \mathrm{m} \mathrm{m}^{-3}\right.$; Sackmann et al., 2004). For this larger dataset we compared actual daytime fluorescence measurements $\left(F_{D}\right)$ with estimates of "unquenched" fluorescence interpolated

from nighttime fluorescence measurements $\left(F_{N}\right)$. The fluorescence quenching parameter, DFQ (Eq. 2), was used to diagnose the degree of daytime quenching. When $D F Q=0$, fluorescence is completely unquenched; in contrast, when $D F Q=1$, fluorescence is completely quenched. Consistent with our observations from the continental shelf in April 2002, much of the variability in near-surface fluorescence $(0-5 \mathrm{~m})$ in these offshore waters was related to a diel rhythm in fluorescence that was not observed in $\mathrm{b}_{b p}(700)$ (Fig. 5a vs. b).

Although true negative values for DFQ are not expected, negative values of DFQ $(<0)$ were observed, particularly over the continental slope and associated with strong spatial gradients. A difference in biomass along a gradient could result in underestimate of both $F_{N}$ and the fluorescence quenching parameter. Calculation of a similar parameter for backscattering provides an estimate of error for this approach. If the method had no error, the analogous backscattering parameter $\left[\left(b_{b p}(700)_{N}-\right.\right.$ $\left.\left.\mathrm{b}_{b p}(700)_{D}\right)\right] / \mathrm{b}_{b p}(700)_{N}$ would always equal 0 ; it does not (Fig. $5 \mathrm{~b}$ ), largely due to spatial variability in phytoplankton biomass. However, comparison of the histograms for DFQ 25 and $\left[\left(\mathrm{b}_{b p}(700)_{N}-\mathrm{b}_{b p}(700)_{D}\right)\right] / \mathrm{b}_{b p}(700)_{N}$ clearly shows that fluorescence is positively skewed toward 1 , indicating the effect of quenching, while the similar backscattering parameter is more evenly distributed around 0 . The discrepancy between fluorescence and backscattering histograms decrease with depth, as the degree of fluorescence
5, 2839-2865, 2008

\section{Fluorescene quenching from Seaglider}

B. S. Sackmann et al.

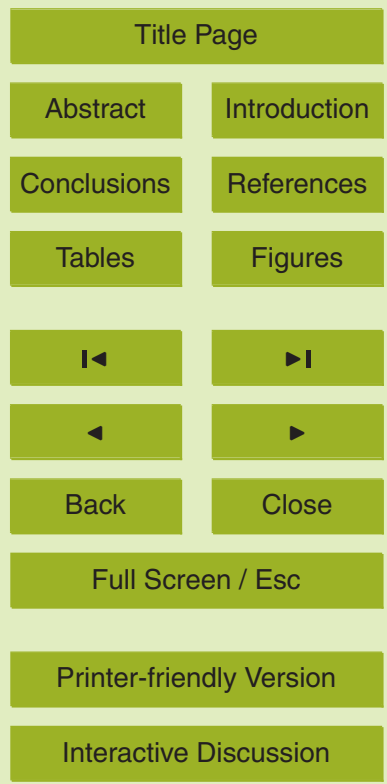


quenching diminishes at lower irradiances (Fig. 5).

We recognize that the effect of "photoinhibitory quenching" may persist for a little while beyond sunset, particularly during the short nights bracketing summer solstice. The average time interval between Seaglider dives was $8 \mathrm{~h}$; in summer, when day

5 length approaches $16 \mathrm{~h}$, it is possible that more of the night-time measurements of $\mathrm{F}_{N}$ could still have some residual quenching. The result would be an underestimate of both $F_{N}$ and the degree of daytime fluorescence quenching; although our reported summer-time reductions in fluorescence are large, they may in fact be underestimates (Figs. 6 and 7a).

10 Quenching was present all year, greater in summer due to higher light and longer days and lesser in winter due to lower light and shorter days. We observed values of DFQ>0 (suggesting some level of daytime quenching) in $84 \%$ of the near-surface daytime fluorescence profiles collected from August 2003-December 2005. Considering only values of DFQ $>0$ for the $0-5 \mathrm{~m}$ data, we observed marked variability across

15 a range of timescales, from days to years, that was positively correlated with seasonal changes in SeaWiFS-derived iPAR (Fig. 6). Maximal winter values of DFQ were usually $<0.5$ in contrast to maximal summer values of $>0.8$ (similar to the degree of fluorescence quenching observed on the continental shelf in April 2002; Figs. 2a and $4)$. Data collected around the summer and winter solstice $( \pm 45 \mathrm{~d})$ were analyzed to 20 determine the effect of time of day on quenching (Fig. 7). Although these data suggest a slight trend of higher quenching at mid-day, strong quenching occurred throughout the entire day, consistent with diel time series of fluorescence quenching and variable fluorescence for phytoplankton in the Damariscotta River Estuary, Maine, USA (Drzewianowski, 2008). Clearly daytime quenching must be taken into account at all 25 times of year in these waters in order to properly interpret fluorescence measurements collected near the sea surface.

When values of DFQ were plotted as a function of IPAR the resulting pattern was remarkably similar to that observed by Behrenfeld and Boss (2006) in the eastern Equatorial Pacific in late 2003 (Fig. 8) and data of Drzewianowski (2008). Although

BGD

$5,2839-2865,2008$

\section{Fluorescene quenching from Seaglider}

B. S. Sackmann et al.

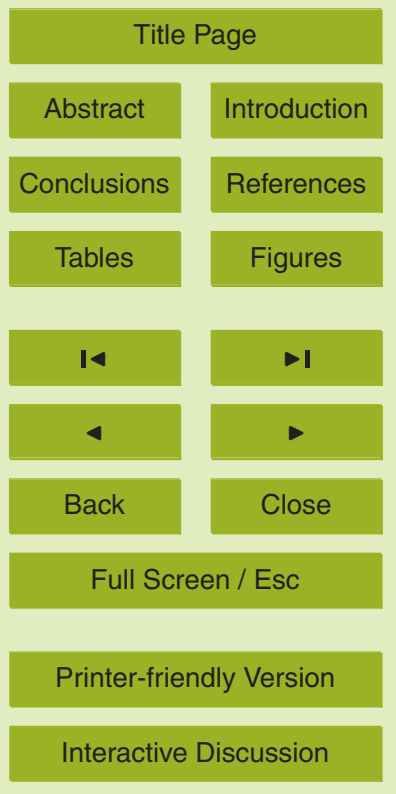


some variability in the Washington data was likely due to the use of SeaWiFS-derived PAR (iPAR) vs. true in situ PAR, these similarities suggest that, at least to first-order, the relationship between incoming solar radiation and the degree of daytime fluorescence quenching can be parameterized by a relatively simple exponential function that

5 could be applicable to a wide-range of oceanographic environments. However, additional measurements from other areas and times of year will be needed to ultimately determine the universality of the prescribed relationship.

While the overall pattern observed in Seaglider-derived estimates of DFQ was similar to what was observed by Behrenfeld and Boss (2006), there were consistent dif10 ferences observed within spatial subsets of the Washington coast dataset. Two spatial subregions, "Slope" and "Oceanic", were defined using the $2200 \mathrm{~m}$ isobath to separate the regions (Fig. 1b; Sackmann et al. 2004). Values of DFQ in "Slope" waters were consistently lower than values observed in "Oceanic" waters for any given value of iPAR. This result suggests that the effects of daytime quenching were proportionally more 15 pronounced in "Oceanic" waters; perhaps the result of higher subsurface irradiances due to low $\mathrm{K}_{d}$ and/or greater nutrient stress for phytoplankton in the more oligotrophic environment (Fig. 8b and c). Because nutrient stress promotes an increase in effective absorption cross-section of PSII, nutrient-limited cells will tend to become photoinhibited at lower photon fluence rates than cells growing in nutrient-rich regimes (Kolber et al., 1988; Falkowski, 1992).

\subsection{Vertical extent of fluorescence quenching}

Daytime fluorescence quenching is likely to be most pronounced near the surface; however, its effects can influence fluorescence throughout the upper water column (e.g. Fig. 5), particularly in clear waters with low values of $\mathrm{K}_{d}$. Histograms of the fluo25 rescence quenching parameter DFQ show that quenching did occur at depth with evidence of slight quenching even below $50 \mathrm{~m}$, particularly during late spring and summer when solar radiation was greater. The extent of fluorescence quenching was reduced at greater depths; for the entire dataset, the median value for the quenching parame-

\section{BGD}

$5,2839-2865,2008$

\section{Fluorescene quenching from Seaglider}

B. S. Sackmann et al.

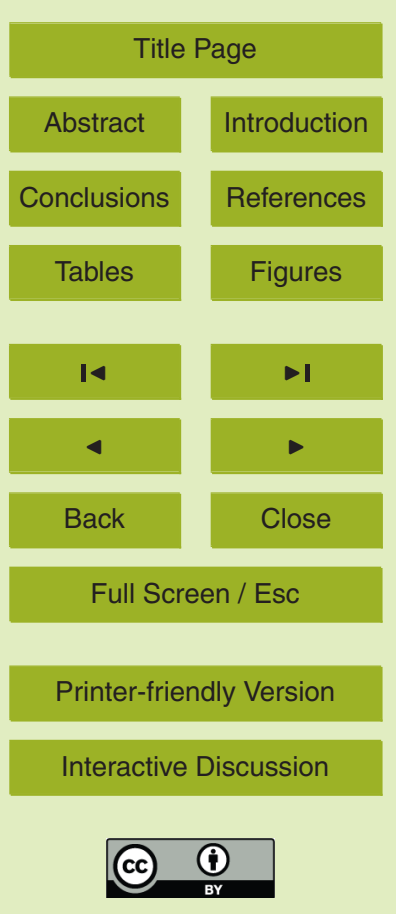


ter was 0.30 for $0-5 \mathrm{~m}, 0.16$ for $5-25 \mathrm{~m}, 0.09$ for $25-50 \mathrm{~m}$, and 0.04 for $50-75 \mathrm{~m}$. In contrast, the median value for the analogous backscattering parameter, $\left[\left(\mathrm{b}_{b p}(700)_{N}\right.\right.$ $\left.\left.\mathrm{b}_{b p}(700)_{D}\right)\right] / \mathrm{b}_{b p}(700)_{N}$, was between $0.02-0.03$ at all depths.

The ubiquitous occurrence of daytime fluorescence quenching can make it difficult

5 to interpret individual fluorescence profiles, especially if they taken out of context. A subsurface fluorescence maximum is a common feature in many parts of the ocean. Unfortunately, without a thorough understanding of daytime fluorescence quenching it could be difficult to determine whether a subsurface fluorescence maximum represents an increase in the quantity of pigment at depth vs. an apparent reduction in pigment 10 due to fluorescence quenching of shallower phytoplankton (we recognize that photoadaptation and an increase in pigment per cell is a third explanation for subsurface fluorescence maxima, cf. Cullen, 1982).

The time it takes phytoplankton cells to recover from the effects imposed by high light intensities varies; factors such as length of exposure, intensity of the ambient light, 15 temperature, and nutrient status will influence the recovery kinetics. Even though the analyses presented here primarily focused on near-surface patterns in daytime fluorescence, there is evidence to suggest that circulation within the mixed layer is fast enough to distribute near-surface phytoplankton populations throughout the mixed layer before full recovery from daytime quenching can be achieved (Denman and Gargett, 1983; Sackmann, 2007). Evidence of quenching also extends well into the afternoon (Fig. 7).

\section{Conclusions}

Our analyses and observations suggest that it is possible to statistically characterize daytime fluorescence quenching using a relatively small suite of optical measurements (i.e. fluorescence, $\mathrm{b}_{b p}$, and some estimate of PAR). As the collection of these mearoutine, it may be possible to dramatically improve fluorescence-based estimates of near-surface chlorophyll-a collected during the daytime. Although satellite-derived

\section{BGD}

$5,2839-2865,2008$

\section{Fluorescene quenching from Seaglider}

B. S. Sackmann et al.

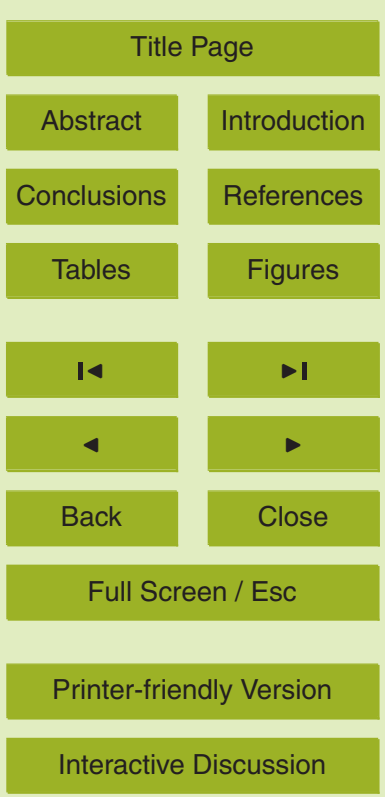


iPAR provided a useful proxy of PAR, direct measurements on the glider would be an improvement. A critical question that remains unanswered is how quantification of quenching can be used to provide information about phytoplankton photophysiology and rates of primary productivity. Recent work by Barnett, Comeau and Cullen (per5 sonal communication), suggesting that the photosynthetic light saturation parameter Ek can be predicted from the irradiance associated with the onset of near-surface decreases in chlorophyll-a fluorescence due to quenching, is an important step in this direction. In summary, we: (i) used a unique bio-optical time series collected from an autonomous underwater glider to characterize variability in daytime fluorescence quench10 ing; (ii) confirmed that daytime fluorescence quenching can be detected in waters off the Washington coast at all times of the year; and (iii) determined that the relationship between daytime fluorescence quenching and incoming solar radiation in phytoplankton off the Washington coast was remarkably similar to observations made in other oceanographic regimes, suggesting a degree of universality for the observed relationship. A critical question that remains unanswered is how quantification of quenching can be used to provide information about phytoplankton photophysiology and rates of primary productivity.

Acknowledgements. We thank the University of Washington Seaglider groups for help throughout development and deployment. We thank the National Ocean Partnership Program and gratefully acknowledge the National Science Foundation (OCE-9911037, 9911036, 0526231, 0526634, Graduate Research Fellowship Program). Thanks to Alan Weidemann, Kristinn Gudmundsson and an anonymous reviewer for their constructive criticism and critique of early versions of the manuscript.

\section{BGD}

$5,2839-2865,2008$

\section{Fluorescene quenching from Seaglider}

B. S. Sackmann et al.

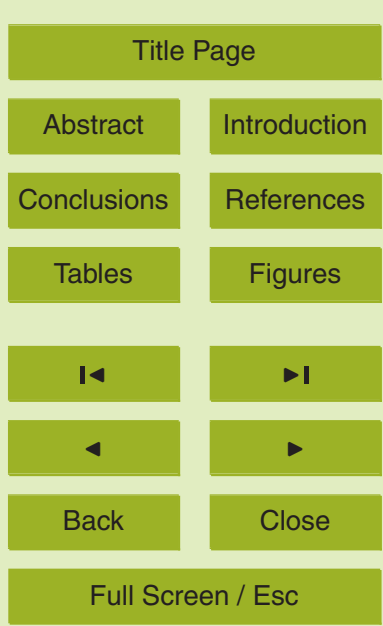

\section{References}

Allen, S. E.: Topographically generated, subinertial flows within a finite length canyon, J. Phys. Oceanogr., 26, 1608-1632, 1996.

Alpine, A. E. and Cloern, J. E.: Differences in in vivo fluorescence yield between three phytoplankton size classes, J. Plankton Res., 7, 381-190, 1985.

Printer-friendly Version

Interactive Discussion 
Alpine, A. E., Cloern, J. E., and Cole, B. E.: Variations in the relationship between in vivo fluorescence and chlorophyll a in the San Francisco Bay Estuary, EOS T. Am. Geophys, Un., 60, 851, 1979.

Behrenfeld, M. J. and Boss, E.: Beam attenuation and chlorophyll concentration as alternative optical indices of phytoplankton biomass, J. Mar. Res., 64, 431-451, 2006.

Behrenfeld, M. J. and Kolber, Z. S.: Widespread iron limitation of phytoplankton in the South Pacific Ocean, Science, 283, 840-843, 1999.

Cullen, J. J.: The deep chlorophyll maximum: comparing vertical profiles of chlorophyll-a, Can. J. Fish. Aquat. Sci., 39, 791-803, 1982.

10 Cummins, P. F., Masson, D., and Foreman, M. G. G.: Stratification and mean flow effects on diurnal tidal currents off Vancouver Island, J. Phys. Oceanogr., 30, 15-30, 2000.

Dandonneau, Y. and Neveux, J.: Diel variations of in vivo fluorescence in the eastern equatorial Pacific: an unvarying pattern, Deep-Sea Res. Pt. II, 44, 1869-1880, 1997.

Demmig-Adams, B. and Adams, W. W.: Photoprotection and other responses of plants to high light stress, Annu. Rev. Plant. Phys., 43, 599-626, 1992.

Denman, K. L. and Gargett, A. E.: Time and space scales of vertical mixing and advection of phytoplankton in the upper ocean, Limnol. Oceanogr., 28, 801-815, 1983.

Drzewianowski, A.: Temporal changes in phytoplankton variable fluorescence (Fv/Fm) and absorption as a result of daily exposure to high light, M.S. thesis, Univ. of Maine, 2008.

20 Eriksen, C. C., Osse, T. J., Light, R. D., Wen, T., Lehman, T. W., Sabin, P. L., Ballard, J. W., and Chiodi, A. M.: A long-range autonomous underwater vehicle for oceanographic research, IEEE J. Oceanic. Eng., 26, 424-436, 2001.

Falkowski, P. G.: Molecular ecology of phytoplankton photosynthesis, in: Primary Productivity and Biogeochemical Cycles in the Sea, edited by: Falkowski, P. G., and Woodhead, A. D., Plenum Press, 47-67, 1992.

Falkowski, P. G. and Kolber, Z.: Variations in chlorophyll fluorescence yields in phytoplankton in the world oceans, Aust. J. Plant Physiol., 22, 341-355, 1995.

Falkowski, P. G., Greene, R., and Kolber, Z.: Light utilization and photoinhibition of photosynthesis in marine phytoplankton, in: Photoinhibition of photosynthesis: from molecular mechanisms to the field, edited by: Baker, N.R. and Bowes, J. Bios Scientific, 407-432, 1994.

Foreman, M. G. G. and Thomson, R. E.: Three-dimensional model simulations of tides and buoyancy currents along the west coast of Vancouver Island, J. Phys. Oceanogr., 27, 1300-

\section{Fluorescene quenching from Seaglider}

B. S. Sackmann et al.

\section{Title Page}

\section{Abstract}

Introduction

Conclusions References

Tables Figures

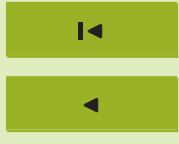

$\rightarrow$

Back

Close

\section{Full Screen / Esc}

Printer-friendly Version

Interactive Discussion 
1325, 1997.

Freeland, H. J. and Denman, K. L.: A topographically controlled upwelling centre off southern Vancouver Island, J. Mar. Res., 40, 1069-1093, 1982.

Kiefer, D. A.: Fluorescence properties of natural phytoplankton populations, Mar. Biol., 22, 263-269, 1973a.

Kiefer, D. A.: Chlorophyll-a fluorescence in marine centric diatoms: Responses of chloroplasts to light and nutrient stress, Mar. Biol., 23, 39-46, 1973b.

Kiefer, D. A. and Reynolds, R. A.: Advances in understanding phytoplankton fluorescence and photosynthesis, in: Primary Productivity and Biogeochemical Cycles in the Sea, edited by:

10 Falkowski, P. G. and Woodhead, A. D., Plenum Press, 155-174, 1992.

Kinkade, C. S., Marra, J., Dickey, T. D., Langdon, C., Sigurdson, D. E., and Weller, R.: Diel bio-optical variability observed from moored sensors in the Arabian Sea, Deep-Sea Res. Pt. II, 46, 1813-1831, 1999.

Kirk, J. T. O.: Light and Photosynthesis in Aquatic Ecosystems, Cambridge University Press, 151994.

Kolber, Z., Zehr, J., and Falkowski, P. G.: Effects of growth irradiance and nitrogen limitation on photosynthetic energy conversion in photosystem II, Plant Physiol., 88, 923-929, 1988.

Krause, G. H. and Jahns, P.: Non-photochemical energy dissipation determined by chlorophyll fluorescence quenching: characterization and function, in: Chlorophyll a fluorescence: a signature of photosynthesis, edited by: Papageorgiou, G. C. and Govindjee, Springer, 463495, 2004.

Kyle, D. J., Ohad, I., and Arntzen, C. J.: Membrane protein damage and repair: Selective loss of quinine protein function in chloroplast membranes, P. Natl. Acad. Sci., 81, 4070-4074, 1984.

Loftus, M. E. and Seliger, H. H.: Some limitations of the in vivo fluorescence technique, Chesapeake Sci., 16, 79-92, 1975.

Lorenzen, C.: A method for the continuous measurement of in vivo chlorophyll concentration, Deep-Sea Res., 13, 223-227, 1966.

Monterey, G. and Levitus, S.: Seasonal variability of mixed layer depth for the World Ocean, NOAA Atlas NESDIS 14, US Gov. Printing Office, Wash., D.C., 96 pp., 1997.

Neori, A., Holm-Hansen, O., Mitchell, B. G., and Kiefer, D. A.: Photoadaptation in Marine Phytoplankton, Plant Physiol., 76, 518-524, 1984.

Ohad, I., Adir, N., Koike, H., Kyle, D. J., and Inoue, Y.: Mechanism of photoinhibition in vivo, J.
BGD

5, 2839-2865, 2008

\section{Fluorescene quenching from Seaglider}

B. S. Sackmann et al.

Title Page

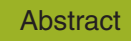

Introduction

Conclusions

References

Tables

Figures

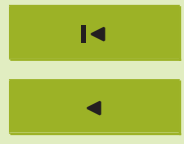

- I

Back

Close

Full Screen / Esc

Printer-friendly Version

Interactive Discussion 
Biol. Chem., 265, 1972-1979, 1990.

Perry, M. J., Sackmann, B. S., Eriksen, C. C., and Lee, C. M.: Seaglider observations of blooms and subsurface chlorophyll maxima off the Washington coast, Limnol. Oceanogr., ALPS issue, in press.

5 Sackmann, B. S.: Remote assessment of 4-D phytoplankton distributions off the Washington coast, Ph.D. thesis, Univ. of Maine, 2007.

Sackmann, B. S., Mack, L., Logsdon, M. G., and Perry, M. J.: Seasonal and inter-annual variability of SeaWiFS-derived chlorophyll a concentrations in waters off the Washington and Vancouver Island coasts, 1998-2002, Deep-Sea Res. Pt. II, 51, 945-965, 2004.

Slovacek, R. E. and Hannan, P. J.: In vivo fluorescence determinations of phytoplankton chlorophyll a, Limnol. Oceanogr., 22, 919-925, 1977.

Stramski, D. and Kiefer, D. A.: Light scattering by microorganisms in the open ocean, Prog. Oceanogr., 28, 343-383, 1991.

Stramski, D., Boss, E., Bogucki, D., and Voss, K. J.: The role of seawater constituents in light backscattering in the ocean, Prog. Oceanogr., 61, 27-55, 2004.

Stramski, D., Reynolds, R. A., Babin, M., Kaczmarek, S., Lewis, M. R., Röttgers, R., Sciandra, A., Stramska, M., Twardowski, M. S., and Claustre, H.: Relationships between the surface concentration of particulate organic carbon and optical properties in the eastern South Pacific and eastern Atlantic Oceans, Biogeosciences, 5, 171-201, 2008,

http://www.biogeosciences.net/5/171/2008/.

Strickland, J. D. H.: Continuous measurement of in vivo chlorophyll; a precautionary note, Deep-Sea Res., 15, 225-227, 1968.

Takahashi, M., Shimura, S., Yamaguchi, Y., and Fujita, Y.: Photo-inhibition of phytoplankton photosynthesis as a function of exposure time, J. Oceanogr., 27, 43-50, 1971.

Vaillancourt, R. D., Brown, C. W., Guillard, R. R. L., and Balch, W. M.: Light backscattering properties of marine phytoplankton: relationships to cell size, chemical composition and taxonomy, J. Plankton Res., 26, 191-212, 2004.
BGD

$5,2839-2865,2008$

Fluorescene quenching from

Seaglider

B. S. Sackmann et al.

Title Page

Abstract

Introduction

Conclusions

References

Tables

Figures

14

$\rightarrow$

4

Back

Close

Full Screen / Esc

Printer-friendly Version

Interactive Discussion 


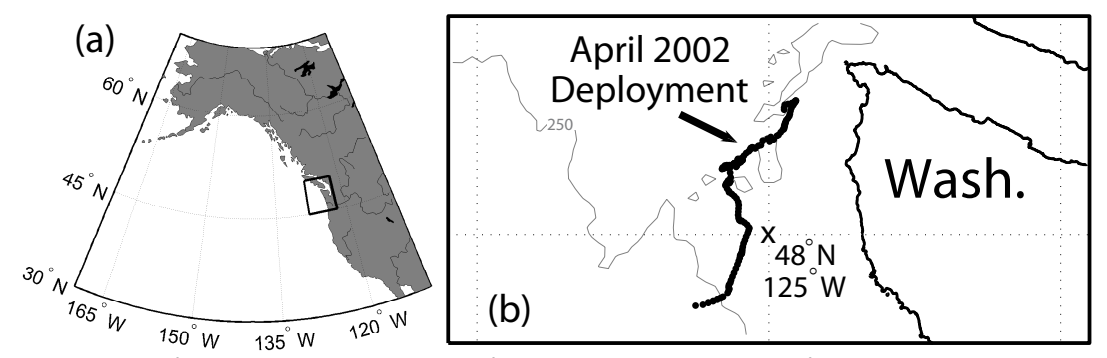

BGD

\section{5, 2839-2865, 2008}

\section{Fluorescene quenching from Seaglider}

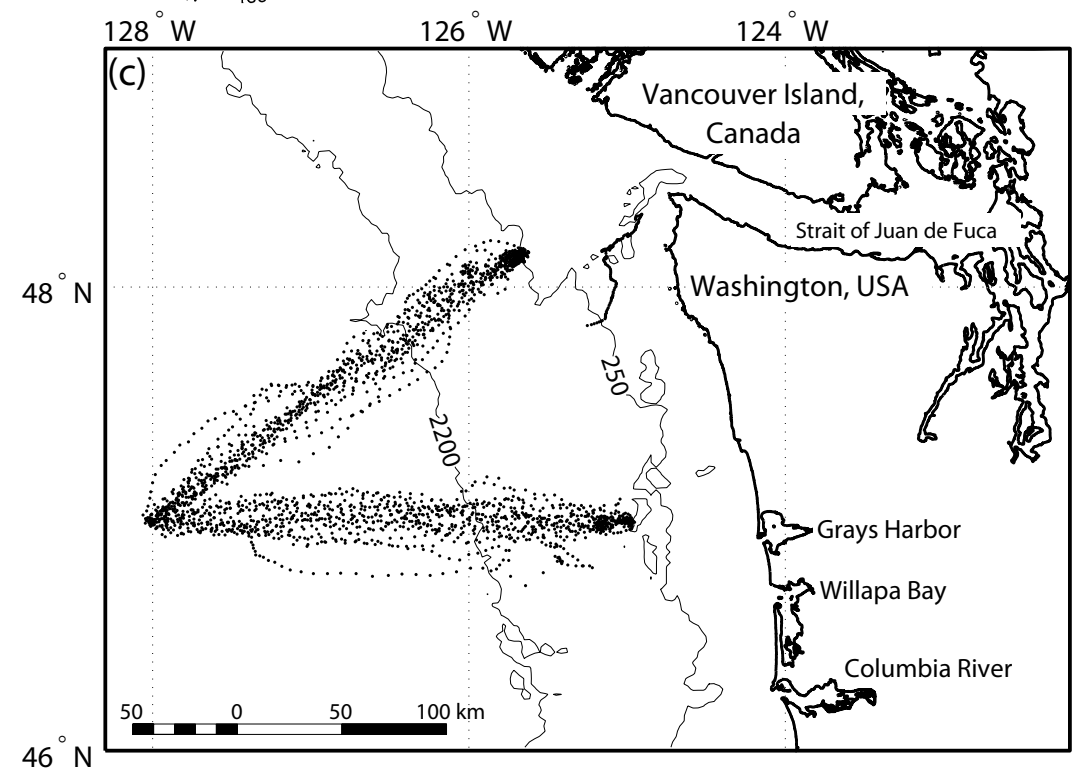

B. S. Sackmann et al.

Title Page

Abstract

Conclusions

Tables

14

4

Back

\section{Full Screen / Esc}

Printer-friendly Version

Interactive Discussion

Fig. 1. Map of (a) northeast Pacific Ocean and $(\mathbf{b}, \mathbf{c})$ Washington coast. Heavy solid line in (b) illustrates portion of April 2002 Seaglider deployment analyzed in text. Dots in (c) denote GPS locations obtained each time Seaglider surfaced from August 2003-December 2005. 


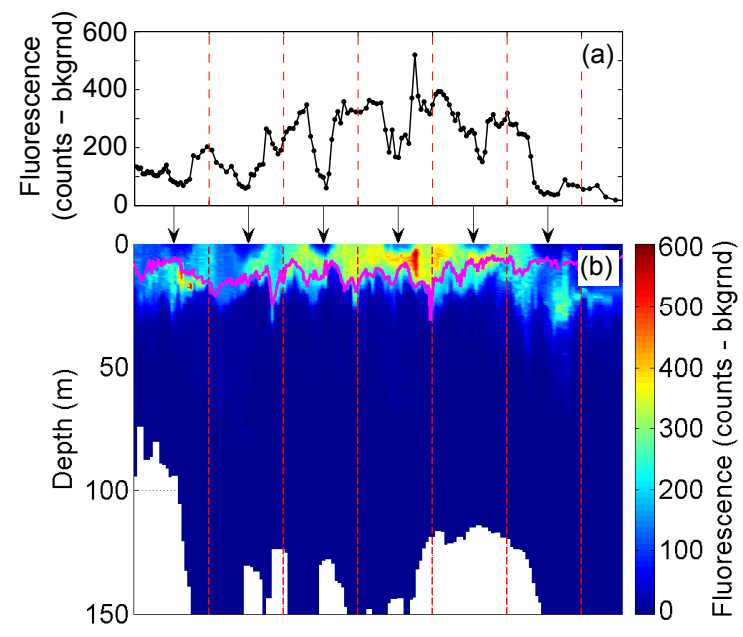

\section{Fluorescene quenching from Seaglider}

B. S. Sackmann et al.
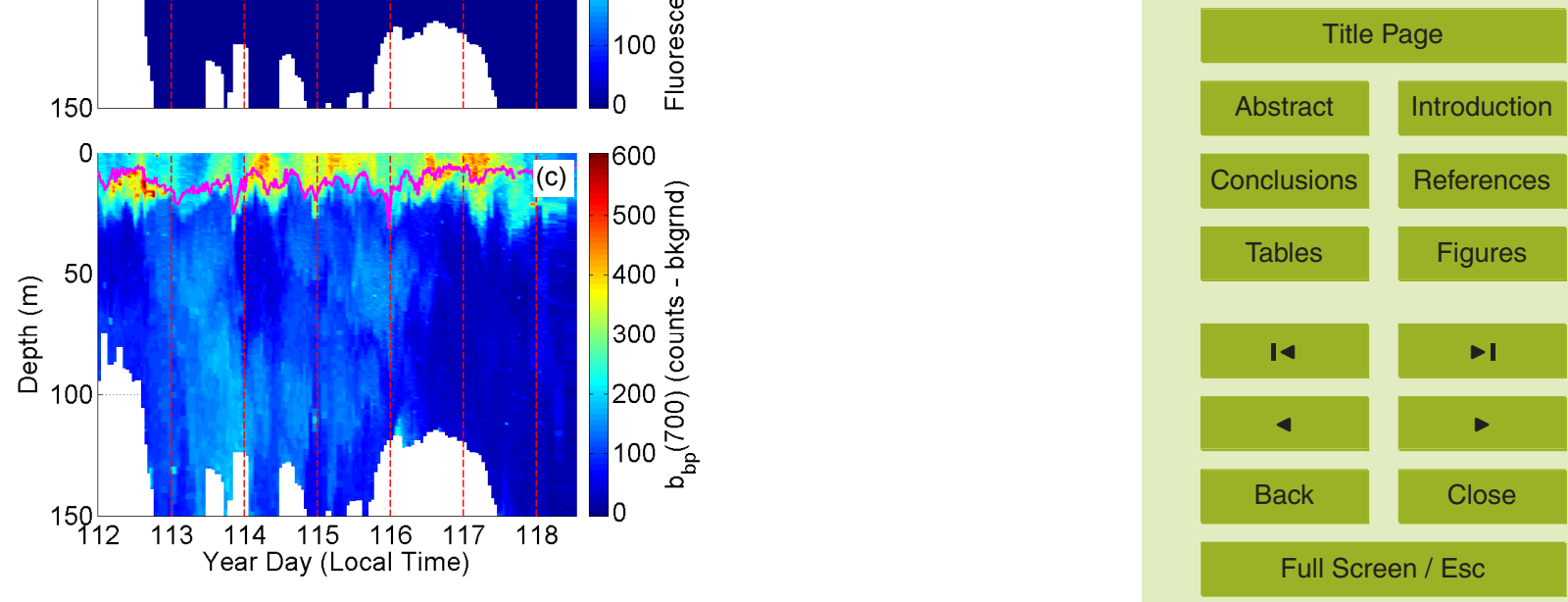

Fig. 2. (a) Median values from near-surface $(0-5 \mathrm{~m})$ for uncorrected fluorescence from April 2002 deployment. Time vs. depth sections of Seaglider (b) chlorophyll-a fluorescence and (c) $b_{b p}(700)$, optical backscattering by particles. Pink line denotes depth of the mixed layer. Arrows point to regions of reduced near-surface fluorescence resulting from daytime quenching. Dashed lines are positioned at midnight for temporal reference. 
BGD

5, 2839-2865, 2008

\section{Fluorescene quenching from \\ Seaglider}
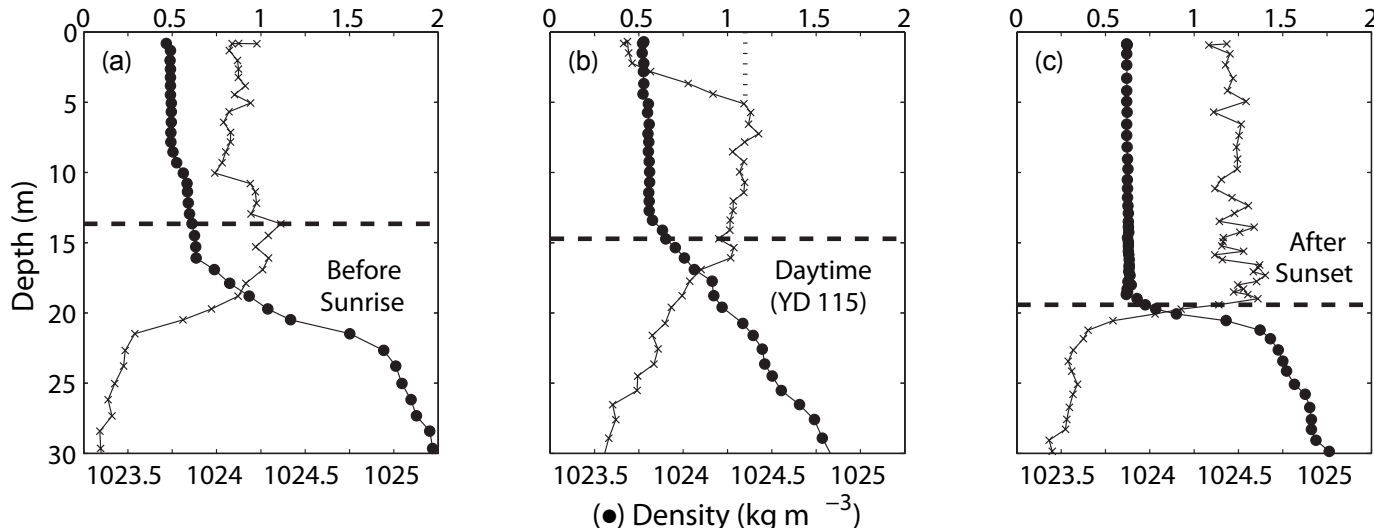

B. S. Sackmann et al.

Title Page

Abstract

Introduction

Conclusions

References

Tables

Figures

(•) Density $\left(\mathrm{kg} \mathrm{m}^{-3}\right)$
$>$ I

4

Back

Fig. 3. Single profiles of fluoresence-to-backscattering ratios $\left(\mathrm{F}: \mathrm{b}_{b p}(700) ;(\mathrm{x})\right)$ and density (filled circles) from YD 115 (a) before sunrise (local time 0448), (b) at mid-day (local noon), and (c) after sunset (local time 2210). The dotted line in panel (b) is the estimated value for $F: b_{b p}(700)$ in the absence of quenching.

\section{Full Screen / Esc}

Printer-friendly Version

Interactive Discussion 


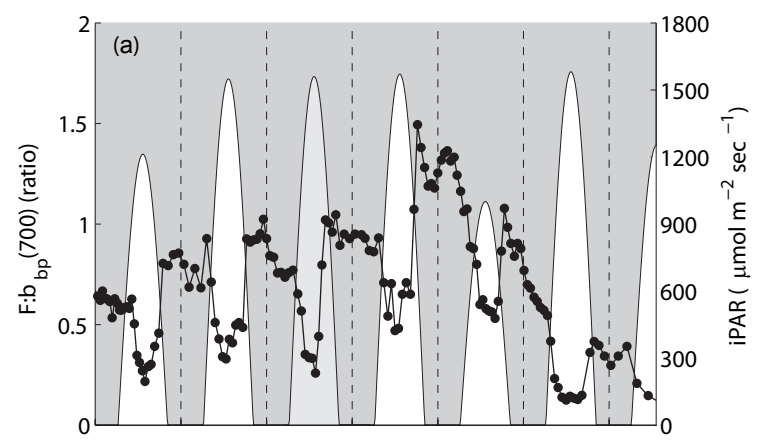

BGD

$5,2839-2865,2008$

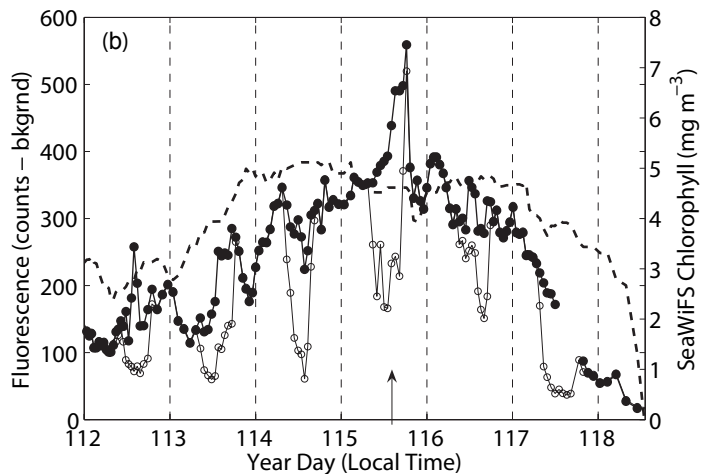

Title Page

Abstract

Introduction

Conclusions

References

Tables

Figures

14

4

Fig. 4. Data from the April 2002 Seaglider deployment; see text for description of methods. (a) Median near-surface values $(0-5 \mathrm{~m})$ of the fluorescence-to-backscattering ratio $\mathrm{F}: \mathrm{b}_{b p}(700)$ (filled circles) and SeaWiFS iPAR (solid line without circles); because a SeaWiFS PAR estimate was not available for YD (Year Day) 114, an average of values from YD 113 and 115 was used to calculate iPAR. (b) Median near-surface $(0-5 \mathrm{~m})$ values of uncorrected fluorescence (open circles) and fluorescence "corrected" using method outlined in text (Eq. 1; filled circles); a few profiles from YD 117 could not be corrected because a region of uniform $F: b_{b p}(700)$ could not be identified (quality control rank $=3$ ). SeaWiFS satellite-derived estimates of chlorophyll-a (dashed line) were extracted from a single scene; arrow denotes when the image was acquired. 

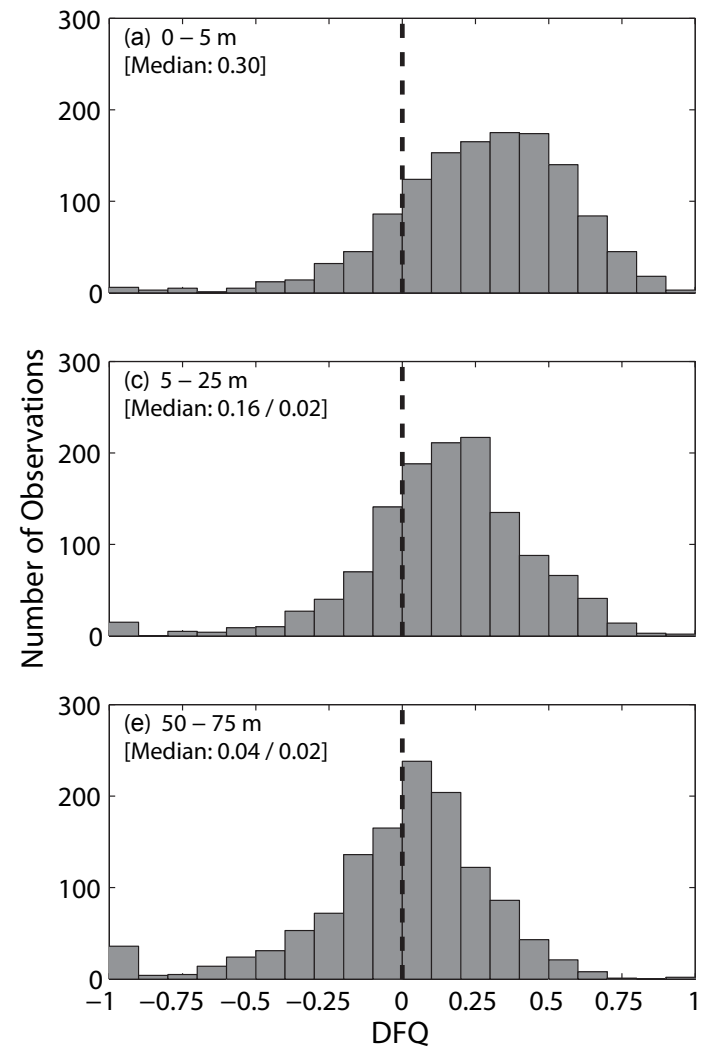
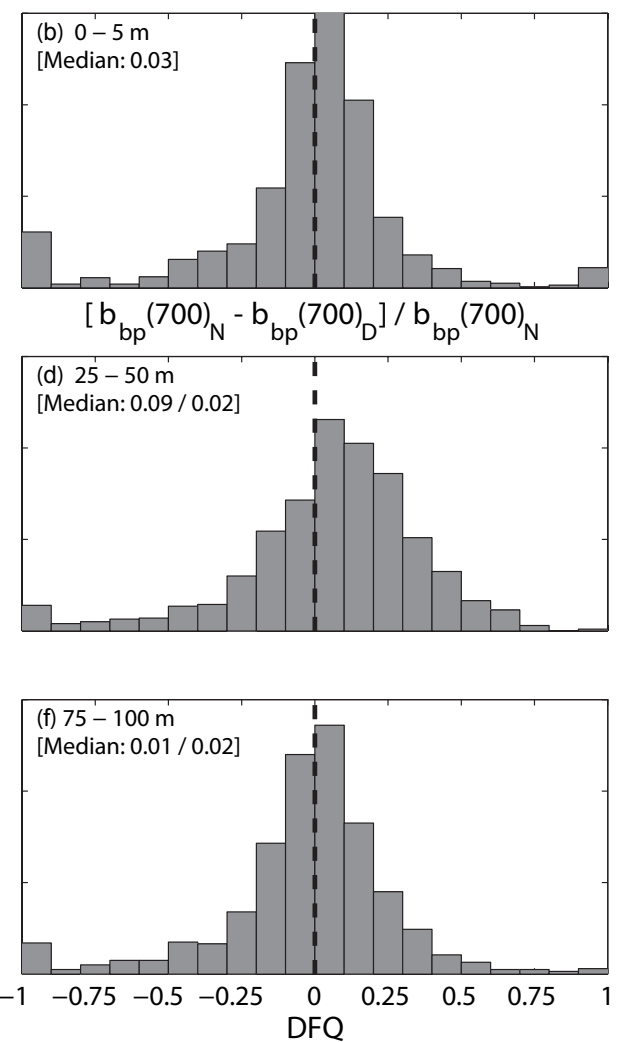

BGD

5, 2839-2865, 2008

\section{Fluorescene quenching from \\ Seaglider}

B. S. Sackmann et al.

\section{Title Page}

Abstract

Introduction

Conclusions

References

Tables

Figures

14

$>$ I

4

Back

Close

\section{Full Screen / Esc}

Printer-friendly Version

Interactive Discussion

Fig. 5. Histograms of (a, c-f) the fluorescence quenching parameter, DFQ, and (b) an analogous parameter based on optical backscattering, $\left[\left(b_{b p}(700)_{N}-b_{b p}(700)_{D}\right)\right] / b_{b p}(700)_{N}$, for all data August 2003-December 2005. Depth bins (a-b) 0-5 m, (c) 5-25 m, (d) 25-50 m, (e) 50$75 \mathrm{~m}$, and (f) $75-100 \mathrm{~m}$. Median values for $\left[\left(\mathrm{b}_{b p}(700)_{N}-\mathrm{b}_{b p}(700)_{D}\right)\right] / \mathrm{b}_{b p}(700)_{N}$ were 0.02 for each depth bin from 5-100 $\mathrm{m}$ (data not shown). 
BGD

$5,2839-2865,2008$

\section{Fluorescene quenching from \\ Seaglider}

B. S. Sackmann et al.
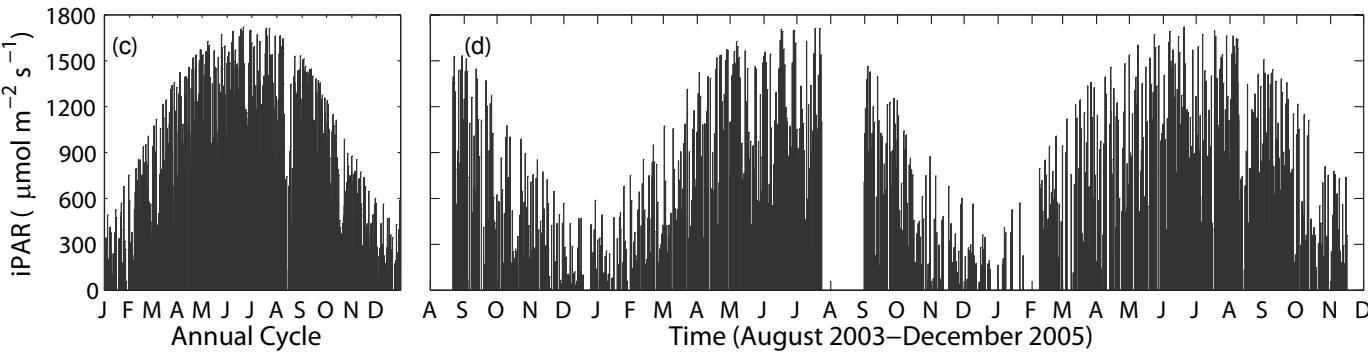

Fig. 6. Seaglider-derived values for (a, b) the fluorescence quenching parameter, DFQ, and (c, d) SeaWiFS iPAR. Data in panels (a) and (c) have been consolidated from data in panels (b) and (d) to better visualize the annual cycle.

\section{Title Page}

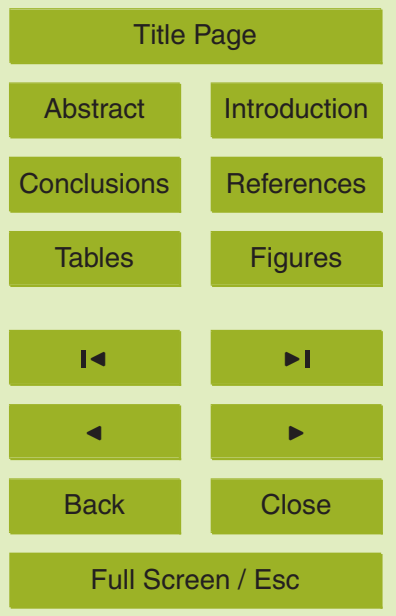

Printer-friendly Version

Interactive Discussion 
BGD

$5,2839-2865,2008$

Fluorescene quenching from

Seaglider
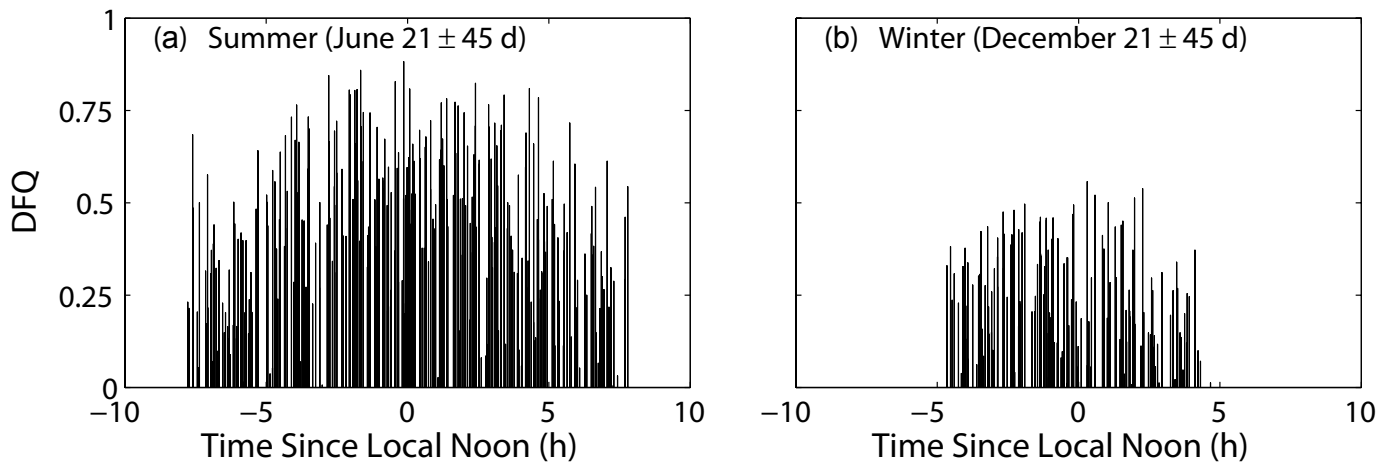

Fig. 7. Seaglider-derived values for $D F Q$ as a function of time before and after local noon for (a) summer (June $21 \pm 45 \mathrm{~d}$ ) and (b) winter (December 21 $145 \mathrm{~d}$ ) for all data August 2003December 2005.

\section{B. S. Sackmann et al.}

\section{Title Page}

Abstract

Introduction

Conclusions

References

Tables

Figures

14

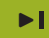

4

Back

\section{Full Screen / Esc}

Printer-friendly Version

Interactive Discussion 


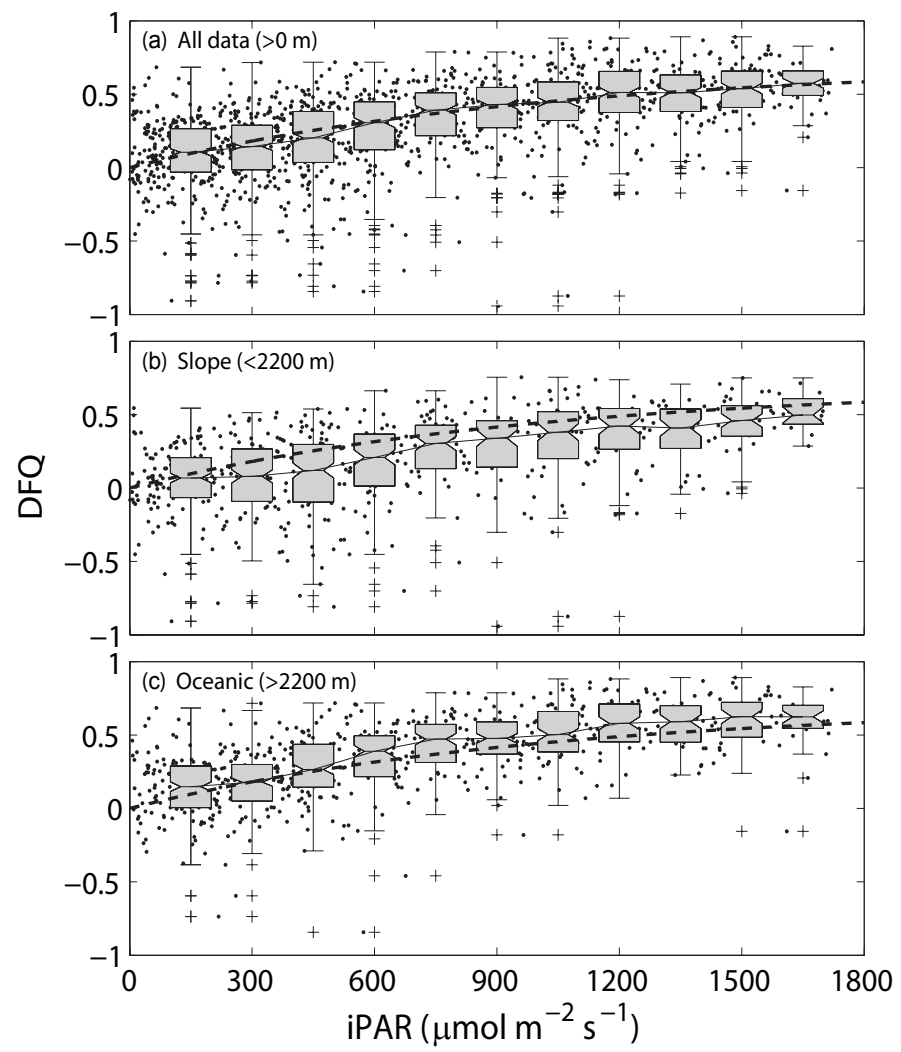

BGD

$5,2839-2865,2008$

\section{Fluorescene quenching from Seaglider}

B. S. Sackmann et al.

Title Page

Abstract

Introduction

Conclusions

References

Tables

Figures

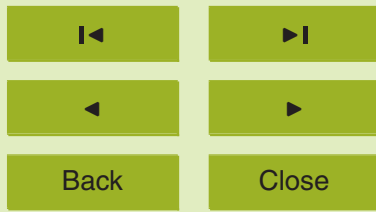

Full Screen / Esc

Fig. 8. Scatterplots of Seaglider-derived values for DFQ versus SeaWiFS iPAR for (a) complete Seaglider dataset, and (b) "Slope" and (c) "Oceanic" subregions. Box plots were calculated from the data using using half-overlapping iPAR bins (i.e. $300 \mu \mathrm{mol} \mathrm{m}^{-2} \mathrm{~s}^{-1}$ ). Regression from Behrenfeld and Boss (2006; dashed line) is included for reference; $\mathrm{DFQ}=1-\left(0.3+0.7 \exp ^{-0.001 \times \mathrm{PAR}}\right)$.

Printer-friendly Version

Interactive Discussion 